\title{
融合蛋白質法による生理活性蛋白質の生産 大腸菌による外来遺伝子産物の汎用的発現生産に期待
}

組換え DNA 技術により大腸菌で真核生物由来の遗 伝子を高いレベルで発現させるためには，一般に trp プ ロモーター, $\lambda \mathrm{P}_{\mathrm{L}}$ プロモーターなどの強力で制御可能な プロモーターを用い，SD 配列を目的蛋白遺伝子の上流 に適当な距離拉よび塩基配列を保つように連結する手段 がとられる.ささらに, 量産化のためには, gene dosage を上げたり, codon usage の検討, 下流域へのターミネ ーターの導入, 宿主側の改良 (lon- ${ }^{-}$株, htpR- 株, $\mathrm{T} 4_{\mathrm{pin}}$ の導入など) が進められる.

しかし，実際には目的遺伀子産物の大量生産に至らな いケースも多い，その理由として，第一に，開始コドン 近傍の mRNA の高次構造の影響により目的遺伝子の翻 訳開始反応が阻害される場合がある(1). 第二に，産生さ れた蛋白質が in vivoで不安定な場合で，特にペプチド ホルモンのような数千ダルトン以下の低分子量のポリペ プチドでは各種のプロテフーゼ作用を受け，速やかに分 解されるようである：最近，ペプチドの等電点 $(\mathrm{p} I)$ と 大腸菌内での安定性との関係が報告(2)されて㔚り, $\mathrm{p} I$ が 高い場合にはin vivo で分解されやすいようである. このように, 外来遺伝子を発現生産するには直接発現法 では限界があるようにみ觉る。また，取得したい遺伝子 産物が臨床的使用を目的としている場合は，直接発現さ せた蛋白質ではそのN末端に開始コドンに由来する Met 残基が付加されることが多く, 蛋白質の安定性, 生理活 性あるいは抗原性に問題が生じる可能性もある。

以上の解決策の一つに融合蛋白質発現法がある.これ は，大腸菌で高発現している遺伝子の蛋白コード領域に 外来遗伝子を連結し, 融合蛋白質として生産させた後, 発現を先導した融合蛋白質部分を化学的，酵素的に処理 乙除去することにより，余分なアミノ酸を含まない目的 遺伝子産物を回収するといら哥であるつまり，翻訳 開始反応は下流の外来遺伝子の影響を受けずに高效率で 進行し，さらに強力なプロモーター支配下で発現させる ことにより融合蛋白質が宿主細胞内に顆粒状 (inclusion body）に形成され，その結果プロテアーゼ耐性が付与さ
れることを期待した方法である，顆粒形成は，本来の立 体構造を有しない目的蛋白質の生産をひき起こすが，一 方で菌体内安定性の増大とそれによる蓄積化，精製工程 の簡便化という利点を与える.この融合蛋白質に特異部 位での切断技術を適用すれば, 天然アミ, 酸配列をるつ 目的遺伝子産物が取得できることになる.

1977 年 Itakura ら ${ }^{(3)}$ は, ヒトソマトスタチン (14 個 のアミノ酸から成り，Met 残基を含まない）遗公子を化 学合成し，大腸菌の $\beta$-ガラクトシダーゼ遗伝子の下流 に Met 残基をコードする合成 DNAを介して連結し， 融合蛋白質を発現させた後, ブロムシアン処理によりメ チオニル結合を特異的に切断してソマトスタチンを得る ことに成功した。 また Goeddel ら゙(4)は，ヒトインシュリ ンの 21 アミノ酸をコードするA鎖と 30 アミノ酸をコ ードするB鎖の遗伝子を別々に化学合成した後，同様に Met 残基を介して $\beta$-ガラクトシダーゼの一部に各々連 結して発現させ, 回収してブロムシアン処理後, A,B両 鎖を酸化し、両鎖間および自己ペプチド中にジスルフ， ド結合を形成させて天然型と同じ組換えヒトインシュリ ンを得ている.このように, 目的遺伝子産物中に Met 残基がない場合には，先導蛋白質の切断法としてブロム シアン処理は有效な手段である. しかし，目的のペプチ ド中に Met 残基が含まれる場合にはこの方法は適用で きないので，切断特買性をもつエンドペプチダーゼが使 われる. Shine. ら占は $\beta$ エンドルフィンの取得に, 内部 Lys 残基をまずシトランニル化して保護しておき，トり プシンでßエンドルフィン直前の $\operatorname{Arg}$ 残基を切断し脱 保護化する手法をとった。一方, Nagai ら(6)は，血液凝 固因子 Xa が Mle-Glu-Gly-Arg のアミノ酸配列を認識

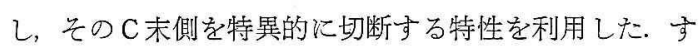

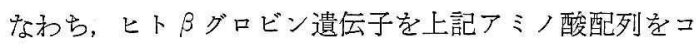
ードする合成 DNA を介して $\lambda C_{\text {II }}$ 遗伝子に連結し, 融 合蛋白質を得た後，Xa 因子で特異的切断を行なって $\beta$ グロビンを取得した：天然蛋白質中に上記アミノ酸配列 が出現する確率は低いので，Xa 因子による切断法は沉

化学と生物 Vol.26, No.1 
用性が高い方法である.

筆者らも，ヒトインターロイキン $2(\mathrm{hIL}-2)$ 遺伝子を 先導蛋白質とする融合蛋白質発現系を作製し, マウスイ ンターロイキン $2(\mathrm{mIL}-2)^{(6)}, \mathrm{BSF}-2^{(7)}$ (B cell stimulatory factor 2) などの高発現生産に成功している，筆者 らは, 大腸菌由来ではなく最初から異種遺伝子産物であ る hIL-2 を顆粒状に蓄積するべクターを基本プラスミ ドに選んだ、また、ヒト血漿カリクレインが Phe-Arg のアミノ酸配列を認識してそのC末側を切断することに 着目し，これをコードする合成 DNA を目的遺伝子の直 前に挿入した. もら一つの工夫として, 先導蛋白質の hIL-2 遺伝子の N末側 59 アミ/酸残基相当分の DNA を,アミノ酸配列を変えずに改変し，できるだけ多くの 制限酵素切断部位をつくった. その理由は, このプロセ スでは, (1)融合蛋白質の顆粒状蓄積, (2)変性状蛋白質か ら活性型蛋白質への変換, いわゆる巻き戻し反応 $(\mathrm{Re}-$ naturing), (3)酵素反応可能な条件下での溶解と酵素切 断，が必須であるが，これらは先導蛋白質のどの領域に 目的蛋白質を連結するかにより大さな影響を受けると考 えられるからである。

以上の構想をもとに筆者らは, trp プロモーター制御 下で著量蓄積する hIL-2 のN末側 4, 12, 21, 51 おょび 59 アミノ酸相当の領域の下流にそれぞれPhe-Arg をュ ードする合成 DNA を介して mIL-2 遺伝子を連結した プラスミドを構築して比較検討した. その結果, hIL-2 部分のアミノ酸残基数 21 の融合蛋白質の場合が, 顆粒 状融合蛋白質の蓄積, グルタチオン酸化還元系による巻 き戻し反応が最も効率よく進行することが判明した。ま た, この融合蛋白質はカリクレインによる切断反応も良 好で, 天然型の mIL-2 を大量に取得できた。

一方, BSF-2 はN末端が Pro であるため, さらにも ら一工夫必要であった. カリクレインは Phe-Arg を認
識してそのC末側を切断するが， C末側が Pro の場合 は切断しないので， mIL-2 で用いた方法をそのまま適 用できない、そこで, 筆者らは, Phe-Arg のかわりに Phe-Arg-Ala 構造を導入した. そしてまず融合蛋白 を巻き戻し, カリクレインによる切断を行ない, Ala[BSF-2] を得た. さらにこれにX-Proを特異的に切断 するアミノペプチダーゼ Pを作用させて Ala を遊離さ せ, 天然型 BSF-2 を高収率で取得できた.

以上, 大腸菌での融合蛋白質発現法の一端を紹介し た.この方法は, ワクチンとしての利用をめざした各種 ウイルスの抗原蛋白質の生産にも用いられている. 目的 遺伝子産物が大腸菌にとって toxic でなければ, ほとん ぞの蛋白質は融合蛋白質として得られるであろう．この 方法の最大の問題点は, 一般にジスルフィド結合を欠き 不活性型で蓄積した融合蛋白質から如何にして活性型の 目的蛋白質を得るかにある. 分子内あるいは分子間にジ スルフィド架橋が多数存在する蛋白質を融合蛋白質発現 法で取得しょうとすれば, かなりの困難を伴らことが予 想される. しかし他方, 一部の蛋白質では菌体外に分泌 させることによって立体構造を形成できたとの報告(2) もあるので, 分泌過程に伴う立体構造形成に関する研究 は, 変性蛋白の物理化学的手段による立体構造形成研究 とともに, 大腸菌を宿主とした融合蛋白質発現法の適用 範囲の拡大につながるものとして期待される.

1) D. Iserentant \& W. Fiers: Gene, 9, 1 (1980).

2) 植田育男 : 生化学, 59, 289 (1987).

3) K. Itakura et al.: Science, 198, 1056 (1977).

4) D. V. Goeddel et al.: Proc. Natl. Acad. Sci. USA, 76, 106 (1979).

5) J.Shine et al.: Nature, 285, 456 (1980).

6) K. Nagai et al.: Nature, 309, 810 (1984).

7) 安枝 寿5：農芸化学会講演要旨, 1987, p. 352 .

8) 鹿島信一ら：農芸化学会講演要旨, 1987, p. 352 .

9) H. M. Hsiung et al.: BIOTECHNOLOGY, 4, 991 (1986).

(山田和彦, 味の素(株)中央研究所)

\section{硝酸還元酵素は細胞内のざこに存在するか 免疫組織学的解析力的蝶菜緑体に局在}

人間をはじめ生物の生育に必要な窒素の大部分は, 植 物のもつ硝酸同化系の㗢きにより供給されている.すな わる，植物細胞内心輸遥された硝酸塩は，まず硝酸還元
酵素 (NR) により亜硝酸塩に還元され, さらに亜硝酸 還元酵素 (NiR) によりアンモニアにまで還元される、 㐋の後,アンモニアはアミノ酸を経てタンパク質, 核酸 
などの重要な生体含窒素化合物へととり込まれていく. 実際, この地上に生育する高等植物のみでも年間 $2 \times$ $10^{4}$ メガトンの窒素が，この硝酸同化系の働きにより有 機化されているといわれている.

$\mathrm{NR}$ は，この硝酸同化系を律速する酵素と考えられて いる. また古くより NR は, 基質である硝酸塩により誘 導される酵素としてよく知られている. 近年の生化学的 手法の進展により，高等植物に打ける NR の共通の性 質がいくつか明らかにされている，たとえば，NADH を生理的電子供与体とし, 分子内に FAD, チトクロム, モリブドプテリンを含み, 分子内電子伝達系を形成して いることなどである(1). しかし，驚かれる読者もおられ ると思らが, NR の細胞内局在性に関しては未だはっき りとした答が出ていないのである.

古くWarburg らの緑藻を用いた実験から, NR 活性 が光照射と密接に関係することが指摘されていた.たし かに Grant らは, 非水系溶媒を用いて, ホウレンソウ やとマワリの NR が葉緑体に局在していることを報告 していた(2). しかし 1972 年, Dalling らは, ショ糖密度 勾配遠心法で, ホウレンソウ, タバュの細胞小器官を分 画し, NR が細胞質に局在していることを示した(3). も し NR が細胞質に存在するとすると, NR 活性の生成物 である亜硝酸塩は細胞質内を移動して葉緑体内にまで運 ばれそここで NiR の基質となると考えなければならな い.しかし，亜硝酸は変異原性もあり，細胞質内を払散 することは合目的的に考えて好都合とはいえない. そ こで, 細胞分画法で NR の局在性を検討している研究 者は, NR は細胞質に存在するが, 葉緑体の表面にゆる く結合しているのではないかと考劣るようになった.

筆者らは, NR の生体内動態を研究課題としている. 研究を進めるにあたり初歩的な疑間のひとつとして，い ったい NR の修飾, 崩解の場は細胞内のどこであろう かといらことがあげられた. そこで NR の細胞内局在 性を再検討し明らかにする必要があった. その際, どの ような手法を用いるかは重要な問題である. 筆者らは, 比較的温和な条件で抗原の局在性を観察できると思われ る免疫組織化学的手法を採用することにした. ただ，残 念ながらこの手法では, 抗体と反応する成分が活性型か 不活性型かは判断できない. しかし最近, Ossmer らは
免疫組織化学的手法の有効性を主張し, 従来細胞分画法 で決められていた酵素タンパク質の局在性を, この免疫 組織化学的手法で再検討する必要性を提案している(4). すでに 1984 年に Vaughn らは, ダイズ子葉の NR が 細胞質のみならず未同定の色素体にも局在することを䖝 光物質をラベルした抗体を用いて報告している(5).

最近, コロイド金粒子をラベルした 2 次抗体を用いた 免疫組織学的解析により, クロレラなどの緑藻類の NR は葉緑体中のピレノイドに局在することが報告され た ${ }^{(6)}$. 筆者らも, ホウレンソウ緑葉 NR の細胞内局在性 の検討に, このコロイド金粒子（直径 $15 \mathrm{~nm}$ )をラへ ルした 2 次抗体を用いる免疫組織学的解析法を採用し た (7). その結果, ホウレンソウ NR は葉緑体のストロマ に局在していると推定された. ごく最近 Roldan らも, 筆者らと同様の手法でホウレンソウ緑葉 NR の大部分 が葉緑体に局在しているという電顕像を得ている(8). と ころで, 葉緑体の起源に関する説得力のある仮説のひと つに共生的起源説がある.つまり, 葉緑体は, ラン藻の ような原核生物が宿主細胞中に内部共生体として生きて いる間に進化したものであるという考え方である. この ような観点にたてば, ラン藻の NR がクロロフィルを 含む膜画分に局在することが知られているので, ホウレ ンソウ NR が葉緑体に局在するとの筆者らの観察は大 変興味深いものである.

さて, NR が葉緑体内に局在すると都合のよい点がい くつかある. まず, 光合成と窒素同化の場が同じオルガ ネラで営まれるとすれば, その相互の制御がより容易で あろう. また，他の硝酸同化系酵素が葉緑体内にあるこ とから, 硝酸同化の効率上も都合がよい.ささらに, NR 活性発現に必要な還元力の供給も心配がない.

しかし残されている問題点も多い. 第 1 に, NR は 根, 胚, 子葉, 花粉など非光合成器官にも広く存在して いる. これらの非光合成器官の細胞では, NR はいった いどこに存在しているのであろらかという疑問である. 第 2 に，なぜ調製された無傷の葉緑体には NR が観察 されないのであろらかといら疑問である. 筆者らの観察 結果は人工産物であるのか, 不活性型 NR なのであろ らか. あるいはホウレンソウ NR は葉緑体からもれ出 易いタンパク質であるのだろらか。第 3 の問題は, ホウ 化学之生物 Vol.26, No. 1 
レンソウ緑葉から調製した poly $(\mathrm{A})^{+} \mathrm{RNA}$ の翻訳産物 から抗 NR 抗体で沈澱するポリペプチドの分子量は, ホウレンソウ緑葉中で生合成された NR のサブュニッ トの分子量と差が認められないことである. 今までのと ころ, 細胞質のリボソーム上で生合成され, 葉緑体中に 輸送されるタンパク質はすべて, そのN末端に“transit ペプチド”と呼ばれる余分なペプチドをもった前駆体と して合成される. transit ペプチドは細胞質で翻訳され たタンパク質が葉緑体の膜を通過するために必要なぺプ チドと考えられている(9). しかし最近, 例外的にミトコ ンドリア内に存在するある種のタンパク質は細胞質で成 熟型と同じ大きさの前駆体として合成されること, さら に成熟タンパク質の $\mathrm{N}$ 末端部分が内在性シグナルを形成 していることが, 動物に限らず植物でも知られてきてい、 る. しかし, 葉緑体内に局在するタンパク質では, 未だ 内在性シグナルを有する分子種は知られていない.はた してNR がこの例のひとつとなるのか否か, NR のN末 端部分の 1 次構造の解析など今後の検討が必要である.

酵素の細胞内局在性は, その生理的機能を考える上で も明らかにしておかなければならない基本的課題のひと つである. 上述のように, 植物の硝酸同化にとって最も

\section{細菌の走化性とカルシウム 枯草菌細胞膜にカルシウムチャンネル}

カルシウムは動物細胞にとって重要なカチオンの 1 つ で，広範な生理活性発現に関与することがわかってお り, 多数の研究者がカルシウムの関与する動物細胞生理 の研究に携わっている. 一方, 微生物でのカルシウムの 役割については不明の点が多く, カルシウムの関与する 顕著な生理現象の報告は非常に少ないが, 酵母でのカル モジュリンの存在が明らかとなり, その増殖や接合現象 時にカルシウムが関与することが示唆されるよらになっ た. 遅ればせながらカルシウムの関与する生理現象が微 生物の世界でも重要な研究課題として登場し始めたわけ である. カルシウムが種々の生理化学現象の制御機構に 関与しセカンドメッセンジャーと言われるようになって 久しいが，その機構の本質に到達するには未だ数々の難 問を解決せねばならないのが現状であり,より単純な微
重要な酵素のひとつである NR の局在性は, いまひと つはっきりしていない現状である.しかし現在, 種々の 方法で世界的に，その局在性が再検討されているので, そう遠くない日に, NR の細胞内局在性にまつわる課題 は解決されるであろら。

1) M. G. Guerrero, J. M. Vega \& M. Losada: Ann. Rev. Plant Physiol., 32, 169 (1981).

2) B. R. Grant, C. A. Atkins \& D. T. Canvin : Planta, 94, 60 (1970).

3) M.J. Dalling, N.E. Tolbert \& R.H. Hageman : Biochim Biophys. Acta, 283, 505 (1972).

4) R. Ossmer, T. Mund, P. L. Hartzell, U. Konheiser, G. W. Kohring, A. Klein, R.S. Wolfe, G. Gottschalk \& F. Mayer : Proc. Natl. Acad. Sci. USA, 83, 5789 (1986).

5) K. C. Vaughn, S. O. Duke \& E. A. Funkhouser : Physiol. Plant., 62, 481 (1984).

6) A. Lopez-Ruiz, J. P. Verbelen, J. M. Roldan \& J. Diez : Plant Physiol.,79, 1006 (1985).

7) K. Kamachi, Y. Amemiya, N. Ogura \& H. Nakagawa : Plant Cell Physiol., 28, 333 (1987).

8) J. M. Roldan, F. Romero, A. Lopez-Ruiz, J. Diez \& J. P. Verbelen: “Inorganic Nitrogen Metabolism", ed. by W. R. Ullrich, P. J. Aparicio, P. J. Syrett and F. Castillo, Springer-Verlag, 1987, p. 94.

9) B. Dobberstein, G. Blobel \& N-H, Chua : Proc. Natl. Acad. Sci. USA, 74, 1082 (1977).

(中川弘毅, 蒲地一成, 千葉大学園芸学部農芸化学科)

生物を用いての研究が有用性を発揮し, 生物学に和ける カルシゥム生理の解明に貢献できる可能性が浮上してき たのである.

さて, 最も単純な細菌でのカルシウムの関与する生理 現象については, 唯一 1977 年に Ordal (1) が細菌の走化 性にその細胞内カルシゥムが重要な役割をもつことを示 唆したに止まり，それ以前はもらろんのこと，それ以 後もこのような明確な現象の報告はない。また, この Ordal の報告さ光，筆者らが枯草菌のカルシウム能動輸 送系の報文原稿を欧州に送った際，彼の仕事を周知の事 実として記載したところ, その訂正を要求されたという 状況であった. Ordal の仕事が他の細菌走化性研究者に 追試不可能であったためその仕事に疑いをるたれてしま っていたようである．細菌の細胞内カルシウムを人為的 
に調節するのは意外に困難で, 大腸菌でも枯草菌でもカ ルシウムを添加していない最少培地中で 10 代程度の継 代培養では生育阻害は認められないし, 同じ 培地中に 10 m M EGTA を加光た場合でもまったく正常に生育す る. また, 細菌細胞内には種々のカルシウムを捕捉する 物質が存在するし，その全体像も不明である. といらわ けで, Ordal によって初めて示唆された細菌でのカルシ ウムの役割は未だ確定されぬままになっていたわけであ った. カルシウムの関与する生理現象はいわば高度に進 化した制御機構に関するものなので, 細菌のよらな未分 化の生物では極く限られた生理現象に止まるものと考兄 ねばならない,

さて, 枯草菌の走化性とカルシウムについての最近の 筆者らの成果を述べるに当って，まず枯草菌のカルシウ ムチャンネルについての説明から始める必要がある、筆 者らが細菌（主として枯草菌と大腸菌）のカルシウム能 動輸送系の解析を開始した当時, 大腸菌に $\mathrm{Ca}^{2+} / \mathrm{H}^{+}$交換 輸送系の存在が示されていたに止まり（この輸送系はカ ルシウムの細胞外排出系としての 役をもつ), その実体 とさらにカルシウムとり込み系についての確かな実験事 実に乏しく，とり达み系が存在するか否か不確実であっ た. そこで，枯草菌と大腸菌について調べたところ，両 細菌に $\mathrm{Ca}^{2+} / \mathrm{H}^{+}$交換輸送系 (exchanger) と $\mathrm{Ca}^{2+}$ 単独 輸送系 (uniporter, 電位依存) が存在し,これら 2 輸送 系により細胞内カルシウムが制御されているだろらと予 想された. exchanger は精製され(2) (分子量 $47 \mathrm{~K}$ の単 一蛋白), その生化学的性質について研究中で, チャン ネルを形成していると考光た汪らが理解し易い事実を得 ているが，未だ確定的ではない。

カルシウムの細胞内とり込みに働く uniporter ${ }^{(3)}$ は, オリゴマー構成であることはほぼ確実であるが, その構 成蛋白の決定には至っていない，この枯草菌の $\mathrm{Ca}^{2+}$ uniporter がチャンネルを形成しているか否かは重要な 問題で, まず手はじめに調べたのが動物の興奮性膜カル シウムチャンネルに作用し近年臨床的に盛んに使用され ているいわゆるカルシウムチャンネルブロッカーと総称 される薬剤の uniporter 活性に対する作用であった。 調 ベたところ, 膜レベルでも精製蛋白による人工膜レベル でも, ブロッカーは明らかに uniporter 活性を阻害し,
特に現在カルシウムチャンネルの指標とさえなっている dihydrobyridine 系の阻害剤である nitrendipine によ って著しい阻害を受け,さらに最近アンボイナ貝に新し く発見され $\omega$-conotoxin と命名されたブロッカーが特 徵的に uniporter 活性を阻害することが判明した.

そこで, チャンネル活性測定に必須な電気生理学的方 法を uniporter に適用することにし, 最近アメリカの Montal により開発され平田肇氏（自治医大）によって日 本にもたらされた人工平面膜法による 枯草菌精製 uniporter の解析を開始したところ, 予想どおり明確なカル シウムチャンネルの活性を uniporter 蛋白は示した. そ

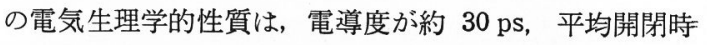
間は $20 \mathrm{msec}$ と算定され, 動物興奮性膜の L-型チャン ネルと同様の V-I 曲線を得, さらにブロッカーに対する 挙動も参考にすると, 枯草菌 uniporter は動物膜の L型のカルシウムチャンネルに相当すると考えてよいよう である.

このよらなカルシウムチャンネルとカルシウム細胞外 排出率 (exchanger, 前述) が枯草菌細胞膜に存在する ことは, カルシウムにより制御される何らかの生理現象 が枯草菌に存在するだろらことを予想させる.ここで筆 者らは Ordal の研究結果に注目することとなった. 通常 の方法で細胞内カルシウムの制御が困難でも, チャンネ ルブロッカーによって生理的に特異的なカルシウムの細 胞内流入が阻害されるだろうことが予想され, 各種ブロ ッカーの存在下，枯草菌のアラニンに対する走化性を測 定することにした. 細菌の走化性測定法にはswarm agar 法と capilary assay 法との 2 法があり,これらの方法に 従って測定したところ, いずれの方法によってもカルシ ウムチャンネルブロッカーは走化性を顕著に阻害するこ とが確かめられた. その阻害度は各ブロッカーのチャン ネル活性阻害度と平行していた. すなわち, 調べられた ブロッカーの中で $\omega$-conotoxin, nitrendipine の阻害が 最も明確に観察された. ここで大事なことは、これらの ブロッカーは枯草菌の運動性には何ら影響なく, ブロッ カー存在下でも枯草菌は正常の遊泳速度 (約 $30 \mu \mathrm{m} /$ sec）で元気よく泳ぐことである.

細菌の走化性は最も始原的な感覚機構の 1 つと考えら れ, 細菌にはその最も基礎的な制御機構が存在すると予 


\section{ヘิ日の話題}

想される. 細菌に走化性誘引物質を与兄ると鞭毛回転方 向の転換が起こり, tumbling から smooth な泳ぎに変 わることが知られている. また, 誘引物質の濃度勾配を レセプターが感知し, 何らかの機構により勾配の高い方 向への運動制御が行なわれていると考兄られる.これら の中でカルシウムの果たしている役割は? 動物細胞, たと壳ば好中球やアメーバの走化性開始時にはカルシウ ムの細胞内増加が認められ，そのカルシウムが種々の細 胞内活性変化を起こし, 最終的に走化性運動へと進むの
であるが, 枯草菌でもカルシウムがどのような細胞内活 性変化と連関しているのかは走化性の基本機構を解明す る上で重要な課題になると思われ，ここで変異株取得の 容易な細菌の有利さが生かされる可能性がある.

1) G. W. Ordal : Nature, 270, 66 (1977).

2) T. Matsushita, T. Ueda \& I. Kusaka : Eur. J. Biochem., 156, 95 (1986).

3) I. Kusaka \& T. Matsushita : J. Gen. Microbiol., 133, 1337 (1987).

(日下 巌, 松下 㻟, 東京大学応用微生物研究所)

\section{害虫の殺虫剤抵抗性亡寄主植物}

摂食する植物の違いで殺虫剤感受性に变化

以前, 殺虫剤の防除試験成績の検討会で, ミカンハダ ニに対する薬剤の効力がナシとミカンで異なる例がしば しば報告された，当時は, 葉の表面構造の違いによる薬 剤付着量の差による結果だろうと想像していた. ところ が最近になって，多種類の植物を寄主にする，いわゆる 広食性昆虫で, 与える植物を変えると殺虫剤感受性が変 化する例が知られるようになって, 昆虫自体にも変化が 起きた結果ではないかと考觉るよらになった。

ハスモンヨトウと同属のヤガ Spodoptera frugiperda の幼虫では，それまで人工飼料で飼育し，6秢になった 直後から 2 日間各種植物を与えて飼った後に殺虫試験を すると、トウモロコシやササゲを与えた幼虫における有 機りん殺虫剤のダイアジノン, メチルパラチオン, メタ アミドホスに対する感受性が，人工飼料で飼い続けた幼 虫に比べ 1/2 以下に低下する. トウモロコシを与竞た幼 虫ではピレスロイド殺虫剤のパーメスリン, サイパーメ スリンに対する感受性も下がる(1).タバコ害虫 Heliothis virescens 幼虫では，トマトや八ッカの葉を与えるとダイ アジノン感受性がそれぞれ $1 / 4,1 / 3$ に低下したと報告さ れている. S. frugiperda 幼虫に各種植物を与えた後, そ の中腸を取り出して殺虫剤解毒にかかわるミクロソーム 酸化酵素とグルタチオン S-トランスフェラーゼの活性 を測定すると，大きく変動している. ミクロソーム酸化 酵素活性はササゲ，ワタを与えると人工飼料や大豆で飼 ったものの 2 倍になり,トウモロコシでは 4.5 倍にも高 まる(1). グルタチオン $S$-トランスフェラーゼ活性はジ
ヤガイモ, トウモロコシ, キュウリ，ワタ，ササゲでは 変化せず, トウガラシ, カブラを与えると 5 倍以上に上 昇したといら(2). さらに, このような酵素誘導 (induction）は, 効果のあった植物の 2 次成分として知られ

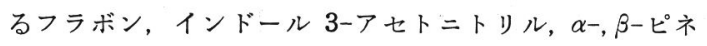
ン, メントール, ハッカ油を人工飼料に添加して与えて も起こる(1,3). 植物の 2 次成分は他種植物との競争, 昆 虫などの食害や病原菌などの感染に対する防御のために 進化途上で獲得されたものと考えられているが，昆虫は それをさらに克服するために解毒酵素を発達させ，殺虫 剂の解毒にも利用しているのである.

殺虫剤解毒酵素としては加水分解酵素もよく知られて いる. この酵素群の呼び名はいろいろあって複雑である が, ここではアリエステラーゼ (AliE) と呼ぶことにす る. アブラムシ, ウンカ, ヨコバイでは抵抗性の発達と AliE 活性の上昇とに平行関係が認められる例が多く, これらの昆虫では $\mathrm{AliE}$ が抵抗性の重要な要因となって いることが同われる. 現在問題となっているワタアブラ ムシの有機りん凮抵抗性においても，非常に高い AliE 活性が伴っている. 拈もしろいことに, 抵抗性個体群が キュウリに限って存在している(4). モモアカアブラムシ では, 抵抗性発達に伴って特定の AliE が虫体蛋白質の 3\% に相当するほど大量に生産されるようになったと報 告されている. この AliE は有機りん化合物やカーバメ イトと強い親和性をもち、これらと結合して不活性化す る sequestration と呼ぶ機能を示す(5). ハスモンョトウ 
幼虫はスミチオンに対して感受性が低い。この幼虫の各 組織から分離される多数の AliE はどれもスミチオンの 活性化体であるスミオクソンに強い親和性をもち, かな りの結合容量があるため, sequestration がその 原因で あろうと考えられる. AliE との親和性の弱いS-プロピ 儿型有機りん殺虫剤がハスモンョトウ幼虫に強い活性を 示すことがそれを裏書きしている(6).

AliE の sequestration は 1 分子当りの能率が分解に比 ベてひどく覀く, 解毒機能を十分に発揮するには量を必 要とするが, 機能発揮に時間を要しないので, 体内での 殺虫剤濃度が急激に上昇するようなときには重要である.

ハスモンョトウ 6 齢幼虫に各種植物を与えた後に中腸 の AliE を電気泳動により分離し，その活性を測定する と, カボチャやナス科植物のトマト, ジャガイモ, ナス の葉を与えたとさには人工飼料, キャベッ, 大豆では現 われない特有の AliE が誘導される. しかし, 中腸の全 $\mathrm{AliE}$ 活性を比較すると人工飼料のほうがトマトの場合 よりはるかに多く，スミチオンに対する感受性も人工飼 料で飼った幼虫のほらが低かった ${ }^{(7)}$. ミカンハダ二の非 休眠系統では, ナシからミカンへ移すと特有の AliE が 誘導され，ミカンからナシに戻すとその AliE が消失す るといら現象が報告されている(8). 前述のミカンとナシ での薬剤感受性の差をこれにより説明することはできな いが，解毒酵素の誘導によることは十分考えられる.

殺虫剤抵抗性の発達は, 上述の解毒酵素を多量に生産 させる遺伝子が殺虫剤使用によって害虫個体群中に蓄積 する過程である. むし, 解毒酵素を多量に生産させる遺 伝子をもつ個体に扎いて寄主植物による誘導が 起こっ て,さらにその生産が増加すれば，その個体が選抜され る確率は一層高まり, 抵抗性の発達は促進される。 た，誘導される酵素がその植物に適応するために必要な 場合には，殺虫凪の淘汰がかからなくても酵素生産の多 い個体は選抜されるはずである。キュウリに寄生してい

\section{茎粒の窒素固定}

\section{マメ科作物の生産性向上に寄与しうるか?}

マメ科植物の最も基本的な特徵は, 根粒菌リゾビウム が共生することによって根粒を形成し，空中窒素を自ら
るワタアブラムシで抵抗性発達が最初に認められた理由 は,このよらなことと推測される．アブラムシは単為生 殖で増殖する期間が長く遺伝子交流の機会が少ないこと と, 分散範囲が限られたことによって抵抗性系統がキュ ウリに留っていた点も, このような例が確認され易かっ た理由であろう. 殺虫剤抵抗性発達の歴史の古いモモア カアブラムシでは抵抗性系統の分散が進んでしまったた めか, 同じような例は現在では認められない。

今日，殺虫剤の主流はピレスロイドに移りつつある. 後続の脱皮阻害剤とともにターゲットでは活性が非常 に強いために，従来の有機りん剤やカーバメイト剤の 1/10 の施薬量で使われている. 高活性化合物指向は殺虫 剂開発の流れとも見えるが，抵抗性の発達し易い方向へ 進むのではないかとの懸念もある.なぜなら，解毒は化 合物のターゲットでの活性とは無関係に行なわれるか ら，過去に高濃度の薬剤に対して解毒酵素生産遺伝子を 蓄積してきた害虫にとっては，その 1/10 の薬剤の解毒 は容易に行なえると考えられるからである，しかし，環 境問題や経済性を考慮すれば，この少量化の方向は変え られないであろら：将来は，個々の害虫種について，殺 虫剤解毒に使われる酵素系と寄主に適応するために必要 な酵素系とを詳しく比較し，その微妙な相違を捕え，き め細い薬剤防除を゙行なわなければならなくなるような気 がする.

1) S. J. Yu : Pestic. Biochem. Physiol., 17, 59 (1982).

2) S. J. Yu : Pestic. Biochem. Physiol., 18, 101 (1982).

3) S. J.Yu : Pestic. Biochem. Physiol., 19, 330 (1983).

4) 浜 弘司: 植物防疫, 41, 159 (1987).

5) A. L. Devonshire \& G. D. Moores : Pestic. Biochem. Physiol., 18, 235 (1982).

6) Y. Kono et al.: Appl. Ent. Zool., 21, 363 (1986).

7）所 尚美, 河野義明：第 31 回応動 昆大会講演要旨, 106 (1987).

8）刑部正博：応動昆, 28, 1 (1984).

（河野義明, 武田薬品工業(株)農薬事業部)

に利用可能なアンモニアに還元できることである. ダイ ズなどの農業上有用なマメ科作物では, 根粒における窒 化学と生物 Vol.26, No. 1 
素固定能力がその収量を規定する主たる要因となってい る. そのため, 共生窒素固定に関する研究の多くは有用 マメ科作物に関するものであり, 宿主とリゾビウムとの 相互関係や共生窒素固定のメカニズムあるいは感染機構 の解明に主要な努力がなされてきた. しかし近年, マメ 科植物の中には根粒以外に茎粒も形成し窒素固定を行な う植物の存在が知られるようになった. 共生窒素固定の 多様性を考える場合, 茎粒に扣ける窒素固定の研究は興 味ある知見を提供するとともに, 根粒の窒素固定研究に もインパクトを与えるものと期待される.

現時点で茎粒を形成するマメ科植物として, クサネム (Aeschynomene), セスバニア (Sesbania), ネプチュニ ア (Neptunia) の 3 属が知られている. クサネム属は主 として熱帯マメ科植物を中心に 160 種より成り, アジ ア, アフリカ, オーストラリアの温帯から熱帯の水田や 川辺などの湿地に生える一年生草本である. 現在調べら れている限り,すべての種で根粒とともに茎粒を形成す る. セスバニア属は約 70 種より成り, 熱帯地方を中心 に広く分布する. 多くは湿地の半低木状草本であるが, 多年生で 小高木となるものもある. 調べられている限 り，根粒を形成し窒素固定を行ならが，茥粒を形成する のはS. rostrata 1 種のみである. ネプチュニア属は熱 帯アジア, マダガスカルに分布する多年生水草で, $N$. oleracea に茎粒が形成されるという古い報告があるもの の, それが窒素固定活性をもつかどうかは不明であり, その後現在に至るまで, この植物の茎粒についての報告 は見あたらない.

さて，クサネムに茎粒が形成され，窒素固定を行なっ ていることを最初に示したのは, 1979 年の谷田沢, 吉 田(1)の報告である. 彼らは, 休耕田を調査中に偶然茎粒 をもつクサネム（A.indica）を見つけ，それが窒素固定 を行ならことを発見したのである.クサネム属の茥粒形 成についてはすでに 60 年近く前に, A. aspera において 湛水した根ぎわ茎部に茎粒が形成されるとの報告はある が，明らかに湛水されないような茥の上部にも茎粒（上 位茎粒) が見つかったのである. この発見を契機に，他 のマメ科植物に拈いても窒素固定活性をもつ茎粒の検索 が行なわれ, 1981 年に Dreyfus と Dommergues ${ }^{(2)}$ はク サネムと同じく熱帯マメ科植物である S. rostrata が窒
素固定茎粒を形成することを報告した． S. rostrata は, 西アフリカのサハラ地方の雨期に冠水する地帯に生育す る植物である.

茎粒を形成する 2 種の植物—クサネムとセスバニ ア一の共通点は, いずれもが発達した通導組織をもっ ており, 過湿な条件にある低地や湛水水田でもよく生育 できることである.この性質は, ダイズなどの有用マメ科 作物をはじめ多くのマメ科植物が過湿に弱いこととは対 照的である. この点と茎粒形成とはなんらかの関連があ りそうである. 自然条件下で生育するクサネムがぞの程 度の頻度で茥粒を形成するかについて調べられている(3) 水田内に生育するクサネムでは, 湛水したとみられる根 ぎわ茎部に集中して茎粒が形成され，茎の上部には茎粒 はまったく認められない，これに対して，水田の道路側 に面した畦畔に自生するクサネムでは, 主茎の上部や側 枝にまで茎粒をもつ個体が $10 \%$ の頻度で見いだされ る. 道路に接しない水田の畦道に 自生するクサネムで は，上位茎粒をもつ個体は見いだされない。自然条件下 で, どのような感染過程で茎粒が形成されるのかは興味 あるところであり，実際にクサネムの根粒および茎粒よ りリゾビゥムが分離され, 茎粒形成の機構について調べ られている(3,4). まず, その分離源が根粒・茎粒のいか んを問わず，リゾビウムが外部より茥表面に付着し，皮 層細胞に侵入することが茥粒形成の絶対条件のようであ る. 一時期, 維管束を通って内部からリゾビウムが皮㬝 細胞に侵入するのではないかと考えられたが，それはな さとうである. その他の条件として，菌の生育に必要な 水分が一定期間保持されることが必要である.このよう な知見をもとに自然条件下での上位茎粒の形成機構を推 論すると, 未舗装の道路端に自生するクサネムにのみ上 位茎粒が形成されるのは, 土着の根粒菌が土埃などとと もにクサネム茎表面に運ばれ，水分などの環境条件が整 ったときに茎粒形成が起こるものと考えられる.

ところで，なぜ茎粒はクサネムとセスバニアにのみし か形成されないのであろらか．この問を解く 1 つの重要 な鍵は植物側の形態的特徵にあるようである.クサネ ム, 七スバニアの双方とも過湿な条件下に生育し, 通導 組織がよく発達している，また，気孔の代わりに空気の 通路となる皮目 (lenticels) が外に突き出している種が 
多いといらことである. 実際, クサネム, セスバニアと も皮目の部分に茎粒が形成されるよらである(2,4,5).ただ し, 皮目の部分より不定根が形成された結果によるもの なのかについては論議のあるところである. クサネムに ついて Eaglesham と Szalay ${ }^{(5)}$ は, 顕微鏡観察により茎 粒の近傍に小さな不定根が認められたとし，一方笹川 ら (4) は不定根の形成は認められなかったとしている. 七 スバニアに括いても不定根の形成についての報告はなさ れていない.クサネムやセスバニアに共生して根粒ない しは茎粒を形成するリゾビウムは, ラッカセイのリゾビ ウムと同様にカウピーグループに分類され，この菌はダ イズなどのリゾビウムとは異なり根毛を経由しないで表 皮の割れ目や支根の分かれ目から侵入する性質をもっ ている、したがって, 不定根の形成は必ずしも茎粒形成 と結びついていないよらに思われる.

最近, 種を異にするクサネム属植物の根粒ないしは茎 粒より 15 種のリゾビウム菌株が分離され, クサネム属 植物 20 種とラッカセイ他 3 種との交互接種試験が行な われた(6). その結果によると, 宿主特異性によって $3 っ$ のグループに分類され, クサネム属間でも宿主と共生菌 との関係はかなり特異性の高いことが示された. この中 で注目すべきことは，グループIに属する菌株（たと えばA. elaphroxylon の茥粒からの分離菌) はラッカセ イに根粒を形成するということである.この事実は, 条
件が整えばラッカセイに茎粒を形成し得るかもしれない という可能性を示唆している.

農業上有用なマメ科作物に茥粒を導入するといらこと は魅力ある課題である. なぜなら, マメ科作物の生産性 はその窒素固定能力に大きく依存し, 茥粒の形成によっ てそれを増強できる可能性があるからである.ささらに, 茎粒について興味あることは, バクテロイドをもつ感染 細胞とクロロプラストをもつ表皮細胞が隣接しているこ とである. このことは, 茎粒が窒素固定に必要な炭素源 を得るのに有利な形態をとっていることを意味してい る.このような茎粒の形態上の特徴は根粒のそれとは明 らかに異なるものであり, 光合成細胞と窒素固定細胞間 での炭素と窒素との物質交換を研究する上からも茥粒は 興味ある対象となろう.

1) M. Yatazawa \& S. Yoshida : Physiol. Plant., 45, 293 (1979).

2) B. L. Dreyfus \& Y.R. Dommergues : FEMS Microbiol. Lett., 10, 313 (1981).

3）吉田重方, 笹川英夫, ブイ・チ・トルン: 熱帯 農 業, 29, 226 (1985).

4) H. Sasakawa, B. C. Trung \& S. Yoshida : Soil Sci. Plant Nutr., 32, 145 (1986).

5) A. R. J. Eaglesham \& A. A. Szalay : Plant Sci. Lett., 29, 265 (1983).

6) D. Alazard : Appl. Environ. Microbiol., 50, 732 (1985). (笹川英夫, 名古屋大学農学部農芸化学科)

\section{癌診断薬としてのモノクローナル抗体 膵癌の腫瘍マーカーなど続々と臨床応用}

細胞融合法により作製されるモノクローナル抗体は, 種々の腫瘍マーカーの検出に利用されている. 固型癌に 対しての臨床的意義は, 血清診断, 生検組織を用いた 癌細胞の 局在診断, 放射性同位元素標識抗体による in vivo 診断などに利用できることである.ここでは, 癌診 断薬として現在広く使用されているモノクローナル抗体 と筆者らの教室で開発した新しい抗体について述べるこ ととする.

$\alpha$ フェトプロテイン(AFP) は肝癌, ヨークサック腫 瘍の診断に広く利用されている腫瘍マーカーである. 化 学療法後あるいは肝動脈塞栓療法後の経過観察に利用さ
れており,すでにその遺伝子のクローン化にも成功して いる. 約 4\%に糖鎖を含み, その差異により肝癌由来の $\mathrm{AFP}$ と肝硬変由来の AFP が区別可能とされ, レンズ豆 レクチン (LCA) や Con A などのレクチンが利用され ているが, AFP 低值 $(10 \sim 50 \mathrm{ng} / \mathrm{ml})$ 例での鑑別は容易 ではなく、したがって AFP の糖鎖構造を詳細に区別し 得るモノクローナル抗体の作製が期待されている.

CEA (carcinoembryonic antigen, 癌胎児性抗原) は 消化器癌, 肺癌 (腺癌), 乳癌などで高值を示す. CEA のペプチド部分と糖鎖部分に対して各種のモノク ローナル抗体が作製されてきたが, 最近 CEA に関する 
国際ワークショップが開催されており，多くのエピトー プをクラスター分類する方向にある. CEA 関連抗原と して nonspecific crossreacting antigen (NCA) グルー プがあげられるが, 最近 CEA, NCA ともクローニング され(1,2), それらの成績より, 従来種々の名称が付さ

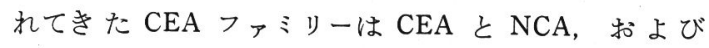
biliary glycoprotein I (BGP-I) の3 種に分けられるこ とが明らかになりつつある，さらに，CEA の 50〜60\% を占める糖鎖構造も判明し, 遺伝子のクローン化の成績 より, CEA の 1 分子に 28 個のアスパラギン結合型糖鎖 が結合し得ることが明らかとなった. 各種モノクローナ ル抗 CEA 抗体の反応性の違いの大部分は CEA 糖鎖に ある可能性があり,ょり高感度で特異性の高いアッセイ 系を求めて研究が新しい局面を迎えている.

CA 19-9(3) は, 培養大腸癌細胞 SW 1116 を免疫原之 して作製されたモノクローナル抗体により認識される抗 原で, 膵癌の腫痬マーカーとして臨床応用されている. エピトープは sialylated lacto- $N$-fucopentaose II で, ヒ ト Lewis a $\left(\mathrm{Le}^{\mathrm{a}}\right)$ 血液型糖鎖の末端にシアル酸の結合 した糖鎖構造を示し, 膵癌, 胆道系の癌, 大腸癌, 胃癌 などの組織に分布する. 正常組織では, 膵管や胆管上 皮, 胃粘膜, 唾液腺にも存在する.したがって, 良性疾 患では胆石症, 胆道や萃管の閉塞に感染の伴った時, あ るいは肝硬変, 卵巣のら腫で軽度上昇することが知られ ている. この場合, Lewis a $\left(\mathrm{Le}^{\mathrm{a}}\right)$ 抗原陰性, Lewis b $\left(\mathrm{Le}^{\mathrm{b}}\right)$ 抗原陰性の患者では fucosyltransferase を持たな いために CA 19-9 は増加しない.それにもかかわらず, このマーカーは膵癌の $60 ８ 0 \%$ に出現するため, これ まで有力なマーカーのなかった膵癌の血清診断的意義は 小さくない, 現在では, より小さな膵癌（径 $2 \mathrm{~cm}$ 以 下）の発見に向けて研究が進められている. 進行膵癌で は、たとえ発見してもその予後が著しく覀いからであ る.

CA 125(4) は Bast らにより作製されたモノクローナル 抗体で, 抗原は胎生期の体腔上皮中の糖蛋白之関倸があ るといわれ，上皮性卵巣癌のマーカーとして有用であ る. さらに, 消化器癌, 特に膵癌でも高值を示すことが ある. 良性疾患では肝硬变で上昇する. 上皮性卵巣癌で は特に漿液性のう胞腺癌に上昇例が多く, ムチン性のう
胞腺癌ではあまり上昇しない.

YH 206 抗体 ${ }^{(5)}$ は筆者らの教室でヒト肺腺癌細胞を免 疫原として作製されたモノクローナル抗体で，抗原は上 記の CA 19-9, CA 125 などと同じく巨大糖蛋白である. 胃癌に $33.9 \%$, 脺癌に $44.1 \%$ の高値を示し, その他胆 のら癌, 肺腺癌でも高值を示す. 良性疾患では肝硬変で 軽度の上昇を見るが，正常ではほとんど上昇しない。 エピトープの性状は, トリプシン, プロテアーゼ抵抗性 で, 過ヨウ素酸およびアルカリ処置に感受性であり, 種 種の検索からアシアロタイプのムチン型糖鎖と 推測さ れ, これまでの腫瘍マーカーと異なる.ささらに最近, YH 206 抗体に対する抗イディオタイプ抗体の作製に成 功した. これにより癌患者血清中に YH 206 抗原に対す る抗体が存在していることが明らかとなった.

また, 最近筆者らの教室の伴らが作製したモノクロー ナル抗体 MUSE 11 は, 膵癌患者の腹水をゲル濾過して 得られた高分子画分を免疫原としたものである. 抗原分 子は $300 \mathrm{k}$ ダルトンの糖蛋白で, エピトープはペプチド と推測される、膵癌および胃癌で強陽性, 大腸癌で陽性 を示し, 正常組織では膵管上皮や腎盘尿細管で弱陽性を 示す. 萃癌患者の陽性率は $60.4 \%$, 胃癌患者では $32.1 \%$ である. 同一萃癌患者血清を用いて, YH 206, MUSE 11 および CA 19-9 抗原を測定してみると, ぞれか 1 つ に陽性を示す例は 15/16 (93.8\%) であり, これらの. combination assay により, ほとんどの膵癌症例を検出 し得る. また Le ${ }^{a}$ 陰性 $\mathrm{Le}^{\mathrm{b}}$ 陰性の患者でも， YH 206 や MUSE 11 は検出可能である. 異なったエピトープを 認識しているモノクローナル抗体の組み合わせが血清学 的診断に利点があると思われ, 今後新しいモノクローナ ル抗体の開発とともに，血清学的診断に役立つ組み合水 せが考えられるものと思われる.

さらに, MUSE 11 抗原で興味ある点は, 膵癌の早期 症例（直径 $2 \mathrm{~cm}$ 以下の小脺癌）に拈いても血清値が上 昇を示す例が経験されたことである. 膵癌は早期発見が 困難で, 手術例を含めてもその 5 年生存率はきわめて低 い.したがって，モノクローナル抗体を用いた早期膵癌 の発見が期待される.

モノクローナル抗体の癌診断における最大の特徵は, 血清により簡便に癌を発見したり, 癌の high risk 
group を特定できる点にある. 今後とも患者に負担をか けず, 経済効率もよいこの分野の発展が期待される所以 でもある. 近い将来, モノクローナル抗体による癌の血 清診断が集団検診に用いられる可能性を筆者らは考えて いる.

筆者らの研究は寿原記念財団の補助によった.

1) S. Oikawa, H. Nakazato \& G. Kosai : Biochem. Biophys. Res. Commun., 142, 511 (1987).
2) J. A. Thompson, H. Pande, R. J. Paxton, L. Shively, A. Padma, R. L. Simmer \& C. W. Todd : Proc. Natl. Acad. Sci. USA, 84, 2965 (1.987).

3) H. Koprowski \& Z. Steplewski : Somatic Cell Genet., 5, 957 (1979).

4) R. C. Bast Jr.: J. Clin. Invest., 68, 1131 (1981).

5) Y.Hinoda, K. Imai, T. Ban, T. Endo \& A. Yachi : Jpn. J. Cancer Res., 78, 607 (1987).

(今井浩三, 小野晃裕, 谷内 昭, 札幌医科大学第一 内科学教室)

プロ $ロ$ ィ

荒井 綜一(Soichi Arai) Vol.23, No. 6 , p. 365 参照

今井 浩三 (Kohzoh Imai) 昭和 23 年 1 月 1 日生 $<$ 略歴 $>$ 昭和 47 年札幌医科大 学医学部医学科卒業 $/ 52$ 年同大学内科学 第一講座助手 $/ 57$ 年同講師, 現在にいた る. この間, 53〜 56年米国 NIH 国際研 究員 (スクリップス研究所), 61 年日本 癌学会奨励賞受賞く研究テーマと抱負 > 尰瘍免疫学, オンュジーン, 分子生物学 的方法による癌の診断などに興味をる。 ていますく趣味〉旅行, テニス

上野 修 (Osamu Ueno) 昭和29年 3 月 2 日生 $<$ 略歴 $>$ 昭和 53 年九州大学農 学部農学科卒業 $/ 58$ 年同大学大学院農学 研究科博士課程修了(農博) $/ 59$ 年同大学 農学部研究生 $/ 61$ 年東京大学応用微生物 研究所研究生 $/ 62$ 年農林水産省農業生物 資源研究所特別奖励研究員, 現在にいた る.この間，58〜 59年米国ニニーヨーク 植物園特別研究員<研究テーマと抱負〉 $\mathrm{C}_{4}$ 光合成の発現機構, 植物の環境適応之 進化の解明<趣味>登山, 自然鑑賞

小野 晃裕 (Akihiro Ono) 昭和 33 年 8 月 3 日生 $<$ 略歴 $>$ 昭和 58 年日本大学医 学部医学科卒業 /同年札幌医科大学第一
内科研究生, 現在にいたるく研究テーマ と抱負>腫瘍免疫, 血液疾患などについ て診断・治療に役立つ研究をしたいと思 いますく趣味〉スポーツ，カメラなど

蒲地 一成 (Kazunari Kamachi) 昭和 38 年 3 月 20 日生 <略歴 > 昭和61年千葉大 学園芸学部農芸化学科卒業. 現在, 同大 学大学院園芸学研究科在学中<研究テー マと抱負 $>$ 硝酸還元酵素の生合成とその 局在化 $<$ 趣味 $>$ 旅行

日下蹒 (Iwao Kusaka) 昭和 7 年 6 月 4 日生 $<$ 略歴 $>$ 昭和 31 年東北大学理 学部生物学科卒業 $/ 36$ 年東京大学大学院 農学系研究科博士課程 (農芸化学) 修了 39 年同大学応用微生物研究所助手 $/ 58$ 年 同助教授, 現在にいたるく研究テーマと 抱負>イオンチャンネルの機能々構造, 微生物細胞構造と生理

河野 義明 (Yoshiaki Kono) 昭和17 年 6 月 1 日生 $<$ 略歴 $>$ 昭和 41 年東京大学 農学部農業生物学科卒業 $/ 46$ 年同大学大 学院農学系研究科博士課程修了 $/ 48$ 年武 田薬品工業(株)入社, 農薬研究所勤務 $/$ 62 年同社農薬事業部開発部勤務, 現在に いたるく研究テーマと抱負>害虫のもつ 種としての生理・生態的な特異性を逆手
にとって防除するような手段を考劣るこ と<趣味>卓球, 碁, 将棋

齋藤 日向(Hiuga Saito) Vol.22, No. 9, p. 590 参照. 現在, 東京大学名誉教 授, 帝京大学教授

笹川 英夫 (Hideo Sasakawa) 昭和 21 年 8 月 22 日生 <略歴>昭和 44 年千葉大学 園芸学部農芸化学科卒業 $/ 49$ 年名古屋大 学大学院農学研究科博士課程修了 $/ 52$ 年 日本学術振興会奖励研究員 $/ 53$ 年名古屋 大学農学部助手, 現在にいたる.この間, 57〜 58年米国コーネル大学内ボイス・ト ンプソン研究所に留学く研究テーマと抱 負>植物生産を規定している機能を解析 乙，それを増強する方策を探りたいく趣 味>草野球, 釣り

高橋 充(Mitsuru Takahashi) Vol. 25, No.11, p. 754 参照

千葉 英雄 (Hideo Chiba) Vol.20, No.9, p. 571 参照

鉄 錫 子 (ペンネーム) 某大学理学 部化学科に在籍. 専門は無機物理化学. 俳句, 俳画, 日曜大工, 陶芸, スキーが 趣味 